Arq. Bras. Med. Vet. Zootec., v.65, n.2, p.377-382, 2013

\title{
Isolation and identification of main mastitis pathogens in Mexico
}

\author{
[Isolação e identificação dos micróbios patogênicos principais \\ da mastite em México] \\ H. Castañeda Vázquez ${ }^{1}$, S. Jäger ${ }^{2}$, W. Wolter ${ }^{2}$, M. Zschöck ${ }^{2}$, \\ M.A. Castañeda Vazquez ${ }^{1}$, A. El-Sayed ${ }^{2,3} *$ \\ ${ }^{1}$ Universidad de Guadalajara - Carretera Guadalajara-Nogales - Zapópan, Jalisco, México \\ ${ }^{2}$ Landesbetrieb Hessisches Landeslabor, Germany \\ ${ }^{3}$ Faculty of Veterinary Medicine - Cairo University, Egypt
}

\begin{abstract}
The present work is a large epidemiological study aiming to detect the prevalence of subclinical mastitis and to investigate the major udder pathogens in Jalisco State, western Mexico. For this purpose, 2205 dairy cows, representing 33 Mexican dairy herds, were involved. Of 2205 cows, 752 mastitic animals were diagnosed and only 2,979 milk samples could be obtained for further investigation. All 2979 milk samples were subjected to California Mastitis Test (CMT) to differentiate clinical cases from subclinical ones where 1996 samples $(67 \%)$ reacted positively. Of these, 1087 samples $(54.5 \%)$ came from cows suffering from clinical cases of mastitis. Bacteriological identification of the causative agents revealed the presence of a major group of pathogens including the Coagulase negative staphylococci (CNS), S.aureus, S.agalactiae, Corynebacterium spp. and Coliform bacteria which were detected in 464 (15.6\%), 175 (5.9\%), $200(6.8 \%), 417(14 \%)$ and $123(4.1 \%)$ of the 2927 investigated quarters, $295(15.4 \%), 118$ (15.7\%), $111(14.8 \%), 227(30.2 \%)$ and $109(14.5 \%)$ of the 752 examined cows and in $33(100 \%), 22$ (66.7\%), $19(57.6 \%), 30(90.1 \%)$ and $27(81.8 \%)$ of the 33 herds involved, respectively. Other pathogens could be detected in the investigated milk samples such as $S$. dysgalactiae $(0.4 \%)$, S.uberis $(0.37 \%)$, Bacillus spp. (1\%), Nocardia spp. (0.6\%) und Candida spp. (0.1\%). Meanwhile, others were present in a negligible ratio; including the Aerococcus viridans, and Enterococcus spp., Lactococcus lactis, S. bovis.
\end{abstract}

Keywords: bovine mastitis, Corynebact spp., Mexico, S.aureus, S.agalactiae

\section{RESUMO}

O trabalho atual é um estudo epidemiológico que objetiva detectar a predominância da mastite subclínica e investigar os micróbios patogênicos principais do úbere no México ocidental. Com esta finalidade, foram utilizadas 2205 vacas leiteiras, representando 33 rebanhos de leiteiras mexicanas. Além dessas 2205 vacas, 752 animais com mastite foram diagnosticados, considerando-se que somente 2979 amostras do leite poderiam ser obtidas para a posterior investigação. Todas as 2979 amostras do leite foram submetidas ao teste da mastite de Califórnia (CMT) para diferenciar casos clínicos dos subclínicos, visto que 1996 amostras (67\%) reagiram positivamente. Além dessas, 1087 amostras (54.5\%) vieram das vacas que sofrem de casos clínicos de mastite. A identificação bacteriológica dos agentes causais revelou a presença dos Staphylococcus negativos para coagulase (CNS), S. aureus, S. agalactiae, outros spp. Streptococcal, Corynebacterium spp., e as bactérias de coliformes foram detectadas em 464 (15.6\%), 175 (5.9\%), 200 (6.8\%), 109 (3.9\%), 417 (14\%) e em 123 (4.1\%) dos 2927 quartos investigados; em 295 (15.4\%), 118 (15.7\%), 111 (14.8\%), 95 (12.6\%), $227(30.2 \%)$ e em 109 (14.5\%) das 752 vacas examinadas e, finalmente, em 33 (100\%), 22 (66.7\%), 19 (57.6\%), 30 (90.1\%), 30 (90.1\%) e em 27 (81.8\%) dos 33 rebanhos envolvidos, respectivamente.

Palavras-chave: mastite bovina, Corynebact spp., México, S.aureus, S. agalactiae

Recebido em 13 de julho de 2011

Aceito em 4 de setembro de 2012

*Autor para correspondência (corresponding author)

E-mail: hcastane59@yahoo.com.mx 


\section{INTRODUCTION}

Mastitis is one of the major diseases in the veterinary field. The worldwide losses due to the disease are approximately $\$ 35$ billion annually. In addition to the huge direct and indirect economic losses, the presence of certain pathogens in the milk threatens public health (Bedolla e Castañeda 2003; Bilal et al., 2004; Wolter et al. 2004).

Mastitis is a complex disease with multiple predisposing factors and various causative agents (Bergdoll 1989, Harmon 1996; Bedolla, and Castañeda 2003; Castañeda 2009; Tollersud et al. 2000). In Mexico, where nearly $1.9 \%$ of the global milk production takes place, the dairy industry has an important share in the domestic product (More, 2009). Therefore, mastitis control is one of the major economical challenges in Mexico. The great economic losses can be reduced only by adopting effective management and control programs. For this purpose and to ensure effective mastitis control, regular and large scale screening studies must be performed periodically to monitor the actual situation in dairy herds. In one of the very few investigations studying the causative agents of mastitis in Mexico, different bacterial species could be isolated from mastitic milk samples including S.aureus, S.agalactiae, Mycoplasma spp., S. uberis, and CNS (Castañeda et al. 2002; Miranda et al. 2008; Castañeda 2009). The prevalence of $S$. aureus in different countries varies greatly. It ranges from $3.0-3.5 \%$ in Finland and Germany and from $34.2 \%$ - $38.5 \%$ in Zimbabwe and Australia, (Daniel et al., 1982; Myllys et al., 1998; Kloppert et al., 1999; Kudinha and Simango, 2002; Milne et al., 2002). In other countries such as USA, Ethiopia, and Brasil the S. aureus was detected in $7.6 \%, 9.1 \%$ and $9.5 \%$, respectively (Bishi et al. 1988, Wilson et al. 1997, Benites et al., 2002). The aim of the present work is to monitor the actual role of different pathogens in the induction of mastitis in Jalisco State, west Mexico and to detect the incidence of subclinical mastitis in relation to clinical cases.

\section{MATERIALS AND METHODS}

In the present work, 2205 dairy cows (33 herds) were examined for mastitis. The majority of the cows (95\% of the animals) belonged to the Holstein Friesian race while the remaining (5\%) belonged to the Jersey, Brown Swiss, Criollo, and Simmental races. The California Mastitis Test was applied to differentiate subclinical cases from healthy ones. A total of 752 mastitic animals were diagnosed and consequently sampled. With the exception of 41 quarters, sufficient milk samples were obtained from the remaining 2,979 quarters. The milk samples were collected under complete aseptic conditions and the samples were kept primary at $4^{\circ} \mathrm{C}$ till being examined within a maximum $12 \mathrm{~h}$ after sampling. The samples were centrifuged at $2000 \mathrm{x} \mathrm{g}$ for $30 \mathrm{~min}$. as recommended by Yousof - Beighi et al. (2005). The sediments were cultured in Blood agar. The grown colonies were subjected to different bacteriological and molecular biological identification processes. All the herds involved originate from 33 dairy herds in the State of Jalisco, Mexico. The farms represent all territories of Jalisco in order to offer a regional epidemiological map of the causative agents genotypes of mastitis in the state.

The milk samples were cultured in sheep blood agar plates with blood agar basis (Merck, Darmstadt, Germany). The plates were prepared according to the instructions from the manufacturer, autoclaved for $15 \mathrm{~min}$ at $120^{\circ} \mathrm{C}$ and left to cool to $50^{\circ} \mathrm{C}$ approximately. After adding 5\% sterile de-fibrinated sheep blood, the liquid agar was then poured in sterile Petri dishes. Before culturing, the samples were warmed to room temperature, mixed thoroughly and centrifuged at $2000 \mathrm{x} \mathrm{g}$ for $30 \mathrm{~min}$. The sediment was taken for this purpose. Finally, the inoculated plates were incubated under aerobe conditions at $37^{\circ} \mathrm{C}$ and read after $24 \mathrm{~h}$ and $48 \mathrm{~h}$, respectively.

In addition to colony morphology and type of hemolysis produced, suspected colonies were also identified by Catalase Test and Tube Coagulase Test (Harmon et al. 1990; Brückler and Schwarz, 1994). The results obtained through the biochemical identification were confirmed by the application of species specific PCR. The API Staph Strip- and the API 20 Strep systems (API System S. A., Montalieu-Vercieu, France) were used to identify the isolated colonies. The systems were used according to the recommendations from the manufacturer. 
The polymerase Chain reaction (PCR) was applied for the molecular confirmation of the results obtained through the biochemical identification. For this purpose, the $S$. aureus species specific primer pair Staur4 (5'- ACG GAG TTA CAA AGG ACG AC -3') and Staur6 (5'-AGC TCA GCC TTA ACG AGT AC-3'; MWG Biotech; Ebersberg, Germany) was used for the partial amplification of the 23S rRNA gene with an amplicon size of 1270 base pairs (bp) according to Straub et al., 1999. The suspected colonies were suspended, subcultured in blood agar and incubated overnight at $37^{\circ} \mathrm{C}$. For the extraction of bacterial DNA, 5-10 colonies were suspended in $100 \mu \mathrm{L}$ TE buffer before adding $5 \mu \mathrm{L}$ lysostaphin $(1.8 \mathrm{U} / \mu \mathrm{L})$ (Sigma, Deisenhofen, Germany). Subsequently, the mixtures were incubated at $37^{\circ} \mathrm{C}$ for $1 \mathrm{~h}$ to enhance cell wall lysis. Followed by the addition of $10 \mu \mathrm{L}$ proteinase $\mathrm{K}(14.8 \mathrm{mg} / \mathrm{mL}$, Roche, Mannheim, Germany), the tubes were then reincubated at $56^{\circ} \mathrm{C}$ for $2 \mathrm{~h}$. The samples were then boiled for $10 \mathrm{~min}$ in order to inactivate the proteinase K. Finally, the mixtures were centrifuged (1min, 10,000g) and the supernatant was frozen at $-20^{\circ} \mathrm{C}$ till being used as a template for the PCR reactions according to El-Sayed et al. (2005).

The reaction mixture $(20 \mu \mathrm{L})$ contained $12.9 \mu \mathrm{L}$ bidest, $0.7 \mu \mathrm{L}$ of both forward and backward primers $(10 \mathrm{pmol} / \mu \mathrm{L}), 0.4 \mu \mathrm{L}$ of dNTP (Biozym, Germany), $2 \mu \mathrm{L}$ of $10 \mathrm{X}$ PCR buffer (Sigma, Germany), $1.2 \mu \mathrm{L}$ of $\mathrm{MgCl} 2$ (25mmol, Sigma), $0.1 \mu \mathrm{L}$ of Taq DNA polymerase $(5 \mathrm{U} / \mu \mathrm{L}$, Sigma). Finally, the template DNA $(2 \mu \mathrm{L})$ was added separately in each reaction tube. The reaction types were then put into the thermocycler (T3 Thermocycler, Biometra, Germany). The PCR products were visualized in a $2 \%$ agarose gel (Roth, Karlsruhe, Germany) in $35 \mathrm{~mL}$ TBE buffer (40mmol/1 Tris, $1 \%$ [v/v] acetic acid, 1 $\mathrm{mmol} / \mathrm{l}$ EDTA). The gels were loaded with $8 \mu \mathrm{L}$ of the PCR product mixed with $3 \mu \mathrm{L}$ of sample buffer (50\% glycerine, $50 \mathrm{mmol} / \mathrm{L}$ EDTA, $0.25 \%$ bromphenole-blue). In addition to the samples, a marker was added to the gel (GeneRulerTM DNA Ladder Mix, MBI Fermentas, St. Leon-Rot; 100Bp DNA Ladder, Gibco/BRL, Eggenstein; DNA length standard VIII, Roche, Mannheim; DNA length standard VI, Roche). The gels were subjected to electrophoretic separation for $1 \mathrm{~h}$ at $100 \mathrm{~V}$ before being stained with Ethidium Bromide for $20 \mathrm{~min}(5 \mu \mathrm{g} / \mathrm{mL}$
Sigma, Deisenhofen, Germany). The gels were evaluated under UV light (gel documentation system Image Master, VDS, Pharmacia Biotech, Freiburg, Germany).

\section{RESULTS}

In the present work, milk samples from healthy, subclinical and clinically mastitic cows in 33 herds of dairy cattle ( $n=2205$ cows) in Jalisco, Mexico were investigated. According to the clinical examination and the CMT results in the studied herds, 752 mastitic animals were diagnosed. Of these mastitic animals, 41 quarters were sever inflamed so they yielded insufficient amounts of milk at the sampling time, therefore were excluded from the statistics. The other 2979 sampled quarters could be divided into healthy quarters $(\mathrm{n}=983)$, subclinically mastitic quarters $(\mathrm{n}=1942)$, clinically mastitic quarters with mild to moderate inflammation $(n=54)$, and clinically mastitic quarters with severe inflammation $(n=41)$. The results are summarized in Table 1 . All 2979 milk samples were tested with the California Mastitis Test (CMT). Of these, 1996 samples $(67 \%)$ reacted positively to CMT. While $1087(54.5 \%)$ of the 2979 samples originated from clinically mastitic cows, only 21 samples $(0.7 \%)$ showed milk clots and $33(1.1 \%)$ showed changes in color. The majority of the samples $2925(98.2 \%)$ were apparently normal. While no bacterial growth could be detected in $53 \%$ of the samples, the grown colonies from the rest of the samples were identified using different tests. These included the analysis of the type of haemolysis in blood agar, results of Api Staph and APi-20 Strept System and Catalase and Coagulase Tests.

For the differentiation between $S$. aureus and the other Coagulase negative staphylococci, beside the results of the Coagulase test, the staphylococcal colonies were subjected to the partial amplification of the $S$. aureus specific gene $23 \mathrm{~S}$ rRNA. The identification of the cultures revealed the presence of different milk pathogens in the samples. Namely; Coagulase negative staphylococci (CNS), S.aureus, S.agalactiae, Corynebacterium spp. and Coliform bacteria were detected in 464 $(15,6 \%), 175(5,9 \%), 200(6,8 \%), 417(14 \%)$ and $123(4,1 \%)$ of the 2927 investigated quarters, $295(15,4 \%), 118(15,7 \%), 111(14,8 \%), 227$ $(30,2 \%)$ and $109(14,5 \%)$ of the 752 examined 
cows and finally in $33(100 \%), 22(66,7 \%), 19$ $(57,6 \%), 30(90,1 \%)$ and $27(81,8 \%)$ of the 33 involved herds, respectively. In addition to these, the $S$. dysgalactiae $(0,4 \%)$, S.uberis $(0,37 \%)$, Bacillus spp. (1,0\%), Nocardia spp. $(0,6 \%)$ und Candida spp. $(0,1 \%)$ could be also detected. Other uncommon pathogens as Aerococcus viridans, Enterococcus spp., Lactococcus lactis, $S$. bovis could also be isolated.

All the $S$. aureus strains isolated coud be identified by PCR with the amplification of the specific gene 23S ARNr (Figure 1).

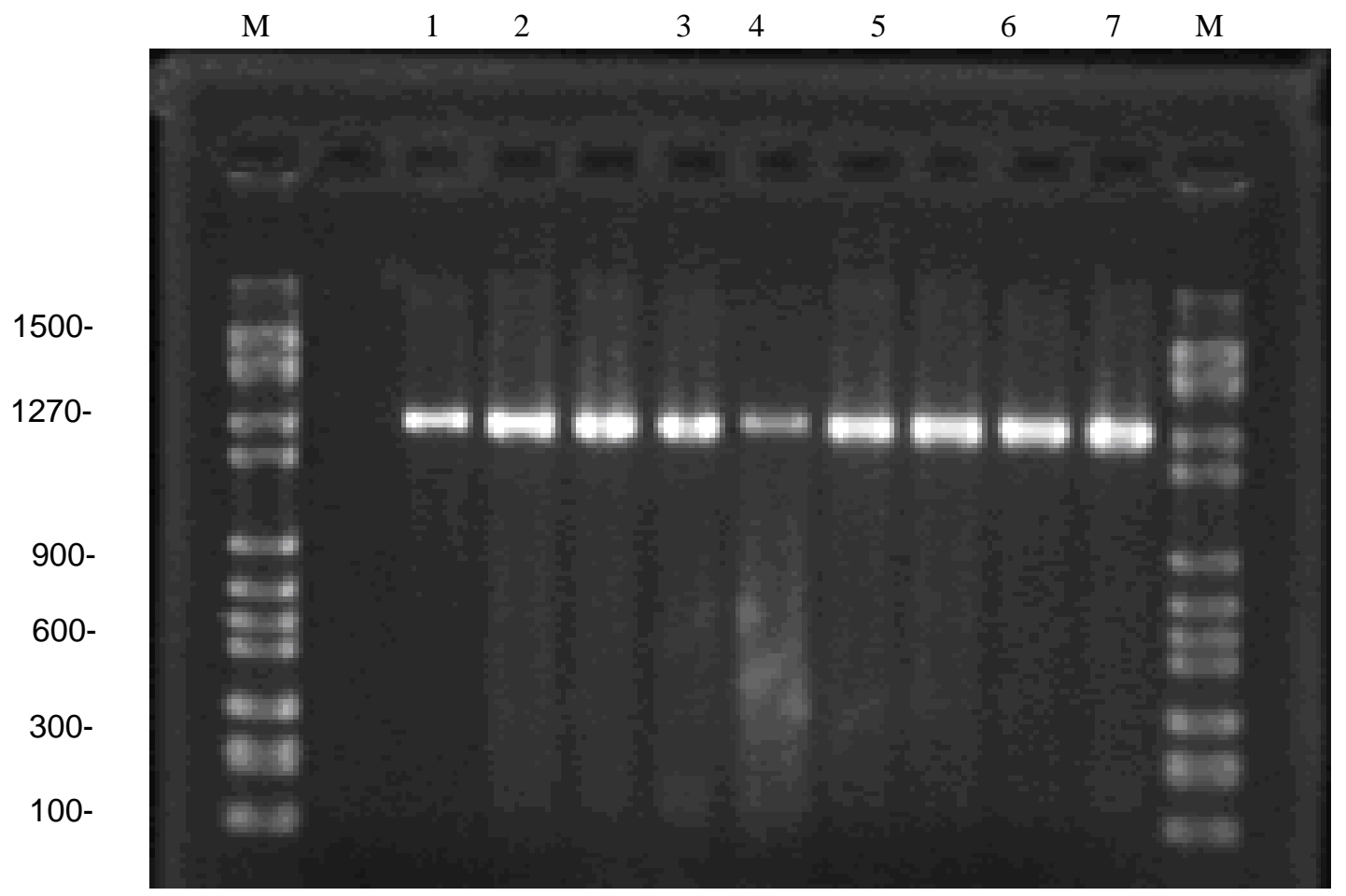

Figure 1. Enlargement of the species specific area of the 23S rRNA gene of $S$. aureus with a uniform enlargement of 1,270 base pairs. $\mathrm{M}=$ molecular weight marker.

Table 1. Subdivisions of milk samples according to physical properties, bacteriological examination and CMT

\begin{tabular}{lcc}
\hline Milk yield & milk samples $(\mathrm{n}=2979)$ & No milk $(\mathrm{n}=41)$ \\
\hline Normal milk (physically) & Normal $(\mathrm{n}=2925)$ & Abnormal $(\mathrm{n}=54)$ \\
Normal milk (bacteriologically) & no growth $(\mathrm{n}=1603)$ & Growth $(\mathrm{n}=1376)$ \\
Normal milk (CMT) & no clumps $(\mathrm{n}=983)$ & Clumps $(\mathrm{n}=1996)$ \\
\hline
\end{tabular}

\section{DISCUSSION}

Although screening of the actual mastitis situation in dairy herds is a very important step in disease control, a very limit number of monitoring studies in Mexico could be found in literature. In the present work, a large monitoring investigation was performed in order to detect the incidence of unremarked subclinical mastitic cases and to detect the main pathogens affecting udder health in Jalisco State, West Mexico. To improve the detection level of the bacteria present in the milk samples, centrifugation of the sampled milk was done at first as recommended previously (Yousof - Beighi et al., 2005). Bacteriological identification of the major causative agents mainly detected the presence of Coagulase Negative Stahpylococci, followed by Corynebact. spp., S.agalactiae, S.aureus, Coliform bacteria, and other bacteria which seem to play a minor role as mastitis inducers such as S. dysgalactiae, S.uberis, Bacillus spp., Nocardia spp. Candida spp. and Aerococcus viridans, Enterococcus spp., Lactococcus lactis, S. bovis. 
The detection level of these bacteria differed according to the type of milk sample, herd and region. This difference in the epidemiological role of different pathogens in the induction of mastitis according to the type of mastitis, herd conditions and the region was also reported by other teams (Castañeda et al, 2002; Medina 2002; Sommerhäuser, 2002; Da Silva et al., 2005; El-Sayed 2006; Eissa 2009). A recent study conducted in central Mexico reported the presence of S. aureus in 30\%; S. uberis in $37.5 \%$ and CNS in $38.3 \%$ of the investigated dairy cows (Miranda et al., 2008). The clear variation in the epidemiology of mastitis and mastitis inducers among different regions in Mexico is surprising. In the present data S.aureus was detected in $15.7 \%$ of investigated cows $30 \%$ in central Mexico) while the S.uberis seems to play a none significant role in mastitis $37.5 \%$ in central Mexico). Yet these differences may be attributed to other factors rather than geographical location, such as the differences in the samples taken or type of mastitis.

The dominance of $S$. aureus as the most prevalent contagious mastitis pathogen is also seen in USA and Mexico, where it was isolated from $43 \%$ of bulk milk samples followed by $S$. agalactiae which was isolated from $3 \%$ of the samples. The high prevalence $S$. agalactiae indicates poor management in investigated farms according to Kloppert et al. (1999). In opposition to our data, $S$. agalactiae was rarely isolated $(0.8 \%$ and $0.12 \%)$ from mastitic milk according to Busato et al., (1997) and Myllys et al. (1998), respectively. Mycoplasma was isolated more frequently in larger herds (Lombard et al., 2008). In the investigated region, the phenotypic $\beta$ haemolysing field strains seem to be of decisive importance as the field strains show a statistically higher significant virulence potential.

\section{CONCLUSION}

The present work offers epidemiological data regarding the situation of mastitis among dairy herds in Jalisco State. The prevalence of both subclinical and clinical mastitis and the role of different mastitis inducing pathogens were discussed.

\section{ACKNOWLEDGMENT}

This study was supported by the Central Laboratories of Hesse State, Germany.

\section{REFERENCES}

BEDOLLA, C.C.; CASTAÑEDA, V.H. Agentes patógenos causantes de la mastitis bovina. Cuatro vientos. n.38, p.27-29, 2003.

BENITES, N.R.; GUERRA, J.L.; MELVILLE, P.A.; COSTA, E.O. Aetiology and histopathology of bovine mastitis of espontaneous occurrence. J. Vet. Med. B Infect. Dis. Vet. Public. Health., v.49, p.366-370, 2002.

BERGDOLL, M.S. Staphylococcus aureus. In: Doyle MP (ed.). Foodborne bacterial pathogens. New York and Basel: Marcel Dekker, 1989. P.463-423.

BILAL, M.; IQBAL, M.; MUHAMMAD, G.; AVAIS, M. et al. Factors Affecting the Prevalence of Clinical Mastitis in Buffaloes Around Faisalabad District (Pakistan). Int. J. Agri. Biol., v.6, p.1, 2004.

BISHI, A.S. Cross-sectional and longitudinal prospective study of bovine clinical and sub-clinical mastitis in peri-urban and urban dairy production systems in the Addis Ababa region, Ethiopia. 1998. (Msc thesis). Berlin: Addis Ababa University and Free University of Berlin, Germany. 1998.

BUSATO, A.; TRACHSEL, P.; SCHALLIBAUM, M.; BLUM, W. Udder health and risk factors for subclinical mastitis in organic dairy farms in Switzerland. Prev. Vet. Med., v.44, p.205-220, 1997.

BRÜCKLER, J.; SCHWARZ，S. StaphylokokkenInfektionen und - Enterotoxine. In: Handbuch der bakteriellen Infektionen bei Tieren. Bd.2/ Teill. Gustav Fischer Verlag Jena, Stuttgart. 1994.

CASTAÑEDA, V.H. Efectos del Staphylococcus aureus en la glándula mamaria en bovinos lecheros. In: SIMPOSIUM SOBRE LA LECHE Y SABERES PARA SU VIABILIDAD COMO ALIMENTO Y OPCIÓN DE DESARROLLO REGIONAL, 1., 2009. Veracruz, Mexico: Universidad de Veracruz., 2009. $9 \mathrm{p}$.

CASTAÑEDA, V.H.; JUNG, H.P.; WOLTER, W.; ZSCHÖCK, M. Occurence and prevalence of bacterial pathogens in bovine mastitis in Jalisco, México. Milchwissenschaften. v.57, p.123-124, 2002.

Da SILVA, E.; CARMO, L.; SILVA, N. Detection of enterotoxins A, B, and C genes in Staphylococcus aureus from goat and bovine mastitis in Brazilian dairy herds. Vet. Microbiol., v.106, p.103-107, 2005.

DANIEL, R.C.; O'BOYLE, D.; MAREK, M.S.; FROST, A.J. A survey of clinical mastitis in SouthEast Queensland dairy herds. Aust. Vet. J., v.58, p.143-147, 1982. 
EISSA, N.M. Molekularbiologischer Nachweis mutmaßlicher Virulenzfaktoren bei Staphylococcus aureus-Kulturen, isoliert von Rindermastitiden. 2008. (Vet. Med. Diss.) Gießen: Justus-Liebig-Universität Gießen, p.1-182, 2008.

El-SAYED, A.; ALBER, J.; LÄMMLER, C.H. et al. PCR-based Detection of Genes encoding Virulence Determinants in Staphylococcus aureus from Birds. J. Vet. Med. B. v.52, p.38-44, 2005.

EL-SAYED, A.; ALBER, J.; JÄGER, S. et al. Comparative studies on genotypic properties of Staphylococcus aureus isolated from clinical and subclinical mastitic cows in México. Vet. México, v.37, p.165-179, 2006.

HARMON, R.J.; EBERHARDT, R.J.; JASPER, D.E. et al. "Microbiological procedures for the diagnosis of bovine udder infections" 3rd ed. Arlington, VA: National Mastitis Council, 1990. p.34.

KLOPPERT, B.; WOLTER, W.; RISSE, K.; ZSCHÖCK, M. Erregerspektrum bei boviner subklinischer Mastitis in hessischen Milcherzeugerbetrieben. In: Tagungsbericht des 23. Kongresses der Deutschen Veterinärmedizinischen Gesellschaft e.v. in Bad Nauheim April. 1999, p.350355.

KUDINHA, T.; SIMANGO, C. Prevalence of coagulase-negative Staphylococci in bovine mastitis in Zimbabwe. Tydsk S. Afr. Vet., v.73, p.62-65, 2002.

LOMBARD, J.; TONYA VAN SLYKE, T.; WELCOME, F. et al. Prevalence of contagious mastitis pathogens on U.S. dairy operations. NMC Annual Meeting Proceedings, p.170-171, 2008.

MEDINA, R.J. Prevalencía e identificación de agentes etiológicos causantes de mastitis bovina en el Municipio de Vista Hermosa Michoacán. 2002. (Tesis de licenciatura). Universidad Michoacana de San Nicolás de Hidalgo, Facultad de Medicina Veterinaria y Zootecnia. Morelia, Michoacán, Mexico. p.1-59, 2002.

MILNE, M.H.; BARRETT, D.C.; FITZPATRICK, J.L.; BIGGS, A.M. Prevalence and aetiology of clinical mastitis on dairy farms in Devon. Vet. Rec., v.158, p.241-243, 2002.

MIRANDA-MORALES, R.E.; ROJAS-TREJO, V.; SEGURA-CANDELAS, R. et al. Prevalence of pathogens associated with bovine mastitis in bulk tank milk in Mexico. Ann. N. Y. Acad. Sci., v.1149, p.300302, 2008.
MORE, S.J. Mexico produces. Mexico (1.9\%), of the world milk Global trends in milk quality, implications for the irish dairy industry. Irish Vet. J., v.62, suppl., 2009

MYLLYS, V.; RIDLL, J.; BJÖRKROTH, J. et al. Persistence of bovine mastitis of Staphylococcus aureus clones as assessed by random amplified polymorphic DNA analysis, ribotyping and biotyping. Vet. Microbiol., v.51, p.245-251, 1997.

MYLLYS, V.; ASPHLUND, K.; BROFELDT, E. et al. Bovine mastitis in Finland in 1988 and 1995 Changes in prevalences and antimicrobial resistance. Acta Vet. Scand., v.39, p.119-126, 1998.

SOMMERHÄUSER, J. Untersuchungen mittels Genound Phänotypisierung zur Epidemiologie von Staphylococcus aureus als Erreger subklinischer Mastitiden in hessischen Milcherzeugerbetrieben im Zuge von Bestandssanierungsmaßnahmen. 2002. Dissertation (Vet. Med.) - Leipzig University, p.1-93, 2002.

STRAUB, J.A.; HERTEL, C.; HAMMES, W.P. A 23S rDNA-targeted polymerase chain reaction-based system for detection of Staphylococcus aureus in meat starter cultures and dairy products. J. Food Prot., v.62, p.1150-1156, 1999.

TOLLERSRUD, T.; KENNY, K.; CAUGANT, D.A.; LUND, A. Characterisation of isolates of Staphylococcus aureus from acute, chronic and subclinical mastitis in cows in Norway. APMIS, v.108, p.565-572, 2000.

WILSON, D.J.; GONZALEZ, R.N.; DAS, H.H. Bovine mastitis pathogens in New York and Pennsylvania: Prevalence and effects on somatic cell count and milk production. J. Dairy Sci., v.80, p.25922598, 1997.

WOLTER, W.; CASTANEDA, H.; KLOPERT, B.; ZCHÖCK, M. Mastitis Bovina, Prevención, Diagnostico y Tratamiento. 1. Ed.. Editorial Universitaria: Universidad de Guadalajara. Guadalajara Jalisco, p.1-146, 2004.

YOUSOF-BEIGHI, G.H.; RAD, M.; HOSSEINI, S.M.; JAFARI, A. Effect of centrifugation of milk samples on bacteriologic culture. Iranian J. Vet. Res., v.6, p.59-61, 2005. 